\title{
THE POWER OF LANGUAGE IN ORWELL'S NOVEL: ANIMAL FARM A PRAGMATIC STUDY
}

\author{
*Tabarak Abdul- Hussein Turkey, **Mazin JasimAl- Hilu (Ph.D) \\ *MA Candidate at Department of English, College of Education \\ **Asst. Prof. at Department of English, College of Literary \\ University of Wasit, Iraq
}

DOI: $10.37648 / \mathrm{ijrssh.v10i02.019}$

Received:10 ${ }^{\text {th }}$ February, 2020; Accepted:04 ${ }^{\text {th }}$ March, 2020; Published: 29th March, 2020

\begin{abstract}
This research is concerned with analysing pragmatically the power of language upon people. The analysis focuses on the British novel, 'Animal Farm' by George Orwell. This study aims at analysing the language used in the novel and showing how it can be used as an oppressive device that can be manipulated to lead to a totalitarian state. The model of analysis that is used in the current study is Grice's theory of implicature and the cooperative principles (1975). The researcher employs qualitative method to have deep understanding and examination to the data of the present study. The results of this research reveal that pragmatic analysis shows that language can be used as a tool to spread power and authority. It can lead to a whole totalitarianism when those in power imply their aims and intuitions in the words they use. The implied meaning occurs when the speaker violates the relevance, the manner, the quality and the quantity maxims and being uncooperative. The study also shows the role and power that the language has upon the thought and behaviour of people
\end{abstract}

Keywords:Power, ideology. pragmatics, Grice's Theory of Implicature and Cooperative Principle.

\section{INTRODUCTION}

The concept of power is indefinable. The term power is studied by different researchers and scholars from different perspectives according to their respective fields. Nagel (1975) declares that the word power "often fosters more disagreement than understanding" (p.4). Clark (1967) on the other hand, states that, "It has been generally true that any single author deals only with those aspects which are of particular importance in clarifying a specific theoretical or empirical problem" (p. 271). For instance, sociologists regard power as social structures, psychologists consider it as a motive or drive, while socio-psychologists define power as the capacity to influence others (Goldberg, 1983, p. 91). 
Sillince (2000) points out that rhetorical power is attained through the use of language. Sillince discovers that people in a high positional power use positive politeness forms of language to reduce conflict and protect people with low positional power from "a sense of loss of respect" and to show intimacy and approval. Even though positional power could have been used to make decisions. Sillince demonstrates that positional power is enhanced by the use of appropriate language forms. Rhetorical power, the use of appropriate words for a specific context and the choice of sentence structure to move and motivate people could be developed through the strength of language use.

Language is defined as the unique human talent that has a great role in molding humans' thoughts and deeds. Language has the exclusive ability to shape the behaviour and learning of its users (Hossain, 2017). Lupyan and Bergen (2015) emphasise that there are specific distinguished forms of expressionsthat constitute the basics of the language and it solely programs human minds. They also empirically argue that language major focus is on molding the functions of human mind.

Berkes (2000) argues that language develops to be mind control tool as well as its crucial goal which is the destruction of imagination and will (Hossain, 2017).

One of the important skills in this life is being able to communicate effectively because human beings need to communicate to fulfill their social needs. Furthermore, real communication does not depend only on the meaning of words in an utterance, but also on realising speakers' meaning (Yule, 2010). That is, the speaker tries to convey particular meaning to the hearer and the hearer tries to recognise the speaker's meaning depending on the context. Therefore, communication requires deep understanding of how language is used from both the speaker and the hearer. The study of language use for communication is the branch of pragmatics (Sari, 2014).
Marin (2014) perceives that language has an influential role in imposing dominance on human mind and suppress individual's autonomy in deeds and thoughts. Marin (2014) states that Orwell vividly shows the power that language has and how the autocratic governments use it as a tool to control the thought of its people.

Orwell explains that language has the power in politics to hide the truth and deceive the public (Berkes, 2000). Although Orwell writes Animal Farm in a form of a fable, he tries to show the important role that language has in shaping human minds and thought because it limits and structures the ideas that people try to express (Soriano, 2010).

The growing as well as the restrictive power of language has been very perfectly illustrated by Orwell in his dystopian novel Animal Farm. The way in which linguistic elements hold the absolute ability to control and shape human thoughts has been represented in the novel in the most striking way. In order to lead general thought to a specific target, language has to be engineered in the required mechanism and in this way it attains whole control over people's minds. The government in Animal Farm gives a threatening shape to the language in order to have such dominance, so language has been used for intimidation than for regular communication (Hossain, 2017).

\section{LITERATURE REVIEW}

Pragmatics is firstly emerged and studied by the American philosophical doctrine of pragmatism. There are some philosophers who have a very important role in the study and development of pragmatics. Some of them are Morris, Wittgenstein, Austin, Levinson, Searle, Carnap, Pierce, Leach and Grice. Wittgenstein and Austin have studied the origin of pragmatics in France, England and Germany in 1930s. Morris plays a great role in the development of pragmatics. He has the opinion that pragmatics should involve some other aspects of society, of nerve, of psychology, and of culture that affect the meanings of the symbols (Abraham, 2016). 
The scope of pragmatics includes the areas to which pragmatics has been extended to. The term 'pragmatics' is far more restricted when it is firstly used by Charles Morris (1938). Morris's great interest has been in semiotics which studies signs and symbols. He defines pragmatics as the study of the relationship between signs and interpreters. Then, Morris elaborates the scope of pragmatics to include biological, sociological and psychological (Levinson, 1983). Currently, pragmatics will include other fields of study such as Sociolinguistics, Neurolinguistics, Psycholinguistics, etc. (Crystal, 1987).

Levinson (1997) defines pragmatics as a new branch of linguistics that deals with aspects of meaning that cannot be studied and understood by the semantic theory only. Pragmatics deals with language in relation to the context or the situation of the utterance.

Pragmatics is defined as the study of 'invisible' meaning or how the hearer recognises the speaker's meaning even if it is not actually said (or written). More closely, pragmatics studies language according to the contexts (Yule, 1996) . Crystal (1985) focuses on the role of the speaker in studying pragmatics. He states that pragmatics is the study of language according to its users, specifically their choices, the constraints and difficulties they face when they use language in social interaction and the effects that the use of language has on the other participants who are involved in communication. Pragmatics is not an old studied branch of linguistics.

Pragmatics is the branch that can study the effect of language upon humans because language reflects the way people see the world and how they use it in daily communication and pragmatics studies language in context. Language choice and language use affect people in a varying degree. The right use of language varies from user to user. Language use has an effect on the power status of people. Actually, language is not just a tool to express users' point of view, it is also used to assert dominance and power in different situations (Finsen, 2016).
Those who have power can use language to exert their influence on people. They can dominate the use of language in their communities through various procedures of language planning and by imposing strict language policies. Talbot, Atkinson, and Atkinson (2003) claim that 'language is crucial in articulating, maintaining and subverting existing relations of power in society, both on global, national and institutional levels and on the local level of interpersonal communication' (P. 1-2).

Wright (2000) argues that 'patterns of language use, particularly the rise and fall of linguafrancas, reveal the changing balances of political power' (p. 119). Different languages, such as Latin, French, and Greek, are regarded as a lingua franca in Europe because of the power they get over the centuries. Their speakers could involve in educated conversations and engage in diplomatic negotiations across borders.

Romaine (1994) argues that the most powerful groups in any society are those who can force their language and thoughts upon the less powerful ones. She uses the known example of Britain where English speakers do not need to learn Welsh or Panjabi, but those speakers are demanded to learn and use English. Consequently, English speakers have the most powerful status in the respective countries. By having the ability to speak this language, speakers of the first language 'English' are given status in the society because they are the powerful speakers. Thus, they have easier admission to employment, education, and several benefits. Still, the power that language has is not always clear.

One of the clearest examples about the relationship between power and language is the colonial relationships. The colonial powers bring with them several things, some good and some bad, to the colonies. The most usual thing they bring is their language, or languages. The colonial powers do their best to encourage the natives to speak these foreign languages. The colonial powers believe that what they are doing is for the benefit of the natives and that the natives could make use from their involvement in the colonial society and the adoption 
of a new and positively 'better' language (Spolsky, $2004)$.

\section{RESEARCH METHODOLOGY}

The current study employs the qualitative research method in investigating the selected extracts. Shank (2002) states that a qualitative method is defined as a form of systematic empirical analysis into meaning. By systematic, Shank means 'planned, ordered and public' (P. 5). Denzin and Lincoln (2000) argue that qualitative research includes an interpretive and naturalistic approach: 'This means that qualitative researchers study things in their natural settings, attempting to make sense of, or to interpret, phenomena in terms of the meanings people bring to them' (P. 3).

The qualitative analysis in this study is devoted to analyse the language used in Orwell's novel; Animal farm pragmatically. The model of analysis used in this study is Grice's theory of implicature and the cooperative principle (1975). This principle is consisted of four maxims that govern the conversation. These maxims are called 'Gricean Maxims' which are: the Quantity maxim, the Quality maxim, the Relation maxim and the maxim of Manner. They go in accordance with the 'Cooperative Principle'. Grice (1989) declares that an implicature arises when there is a violation to any one of the maxims. Speakers' violation to the conversational maxim is only by seeming, not a real violation; the spirit of the maxim, though not the letter, is respected. A speaker may fail to observe the maxims, yet stay within the cooperative principle by the use of implicature (Verschueren \& Ostman, 2009). Grundy (2000) argues that in order to infer the implied meaning or (implicature) of an utterance, the hearers and speakers should know the cooperative principle and its conversational maxims. The researcher will analyse two extracts from the novel. There are two stages of the analysis; the contextual analysis and the pragmatic analysis. The pragmatic analysis is divided into Grice's maxims, the cooperative principle and implicature.

Orwell's repeated use of plain and firm language reflects his faith in ordinary truth. This is evident in the language of the Animal Farm, which is categorised by verbal pithiness and syntactic tidiness. This fairy tale takes the formula of language which becomes a twisty language rather than a clear one. The use of language is the prominent theme in the novel. The rebellion on the farm is a languagefocused activity, a product of precisely aggressive linguistic energy, and language, which can efficiently control reality, is at the heart of the tragic experience rather than merely reflecting it. The animals with a para-language (an underdeveloped language) are overcome by the linguistic skill of the pigs. They are unskilled readers of the pigs' deceitful texts (Elbarbary, 1992). 


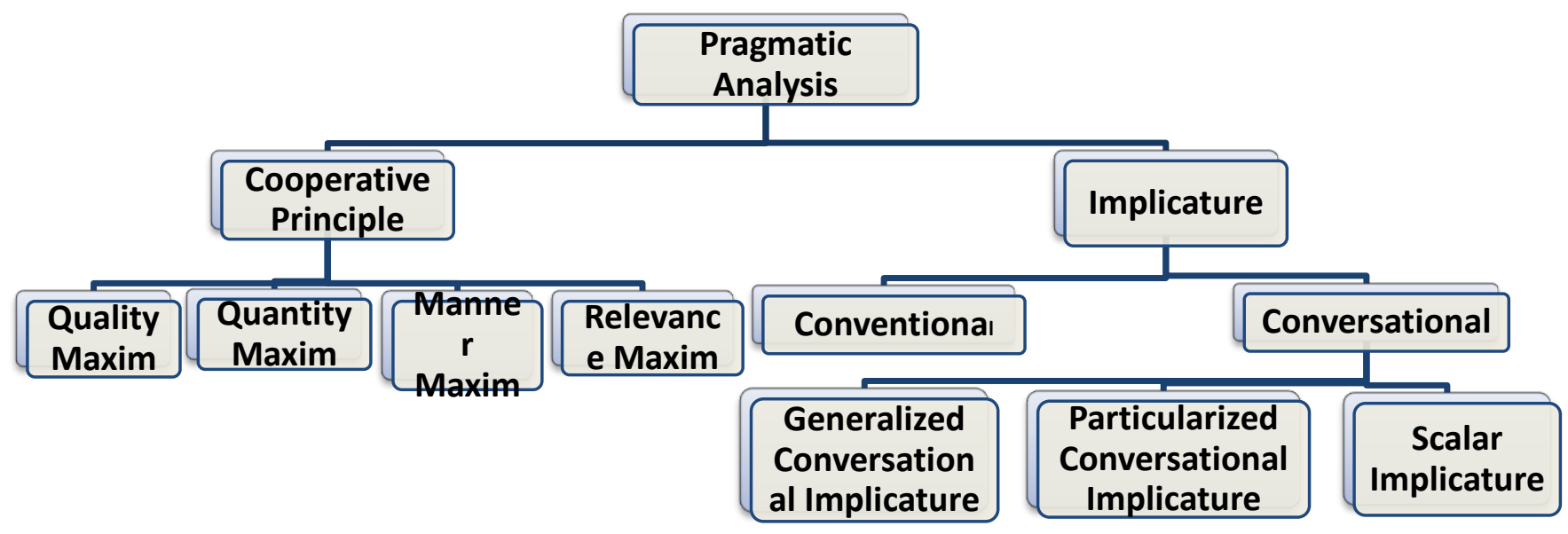

Figure 1 : The proposed theoretical framework for pragmatic analysis[adopted from Grice's Theory of Implicature (1975).

\section{DATA ANALYSIS}

In this section, the data will be analysed according to Grice's theory of Implicature and the cooperative principle (1975).

\subsection{Analysis of Extract 1}

"Comrades! 'he cried. ' You do not imagine, I hope, that we pigs are doing this in a spirit of selfishness and privilege? Many of us actually dislike milk and apples. I dislike them myself. Our sole object in taking these things is to preserve our health. Milk and apples (this has been proved by Science, comrades) contain substances absolutely necessary to the well-being of a pig. We pigs are brainworkers. The whole management and organisation of this farm depend on us. Day and night we are watching over your welfare. It is for your sake that we drink that milk and eat those apples. Do you know what would happen if we pigs failed in our duty? Jones would come back! Yes, Jones would come back! Surely, comrades, 'cried Squealer almost pleadingly, skipping from side to side and whisking his tail, 'surely there is no one among you who wants to see Jones come back?" (N1:P. 11)

\subsubsection{Contextual Analysis}

This extract is taken from the British novel Animal Farm (1945). This extract is said by Squealer to the animals in the Farm to justify the disappearance of milk and apples. Squealer is able to manipulate the animals' thoughts through his hollow convincing rhetoric. Every time the pigs face any objection from the animals, Squealer creates an excuses suitable to the situation. In this extract, Squealer justifies the pigs' use of milk and apples to the well-being of the pigs because they are 
brainworkers for the benefit of all animals. He says that the pigs work day and night for all animals without taking anything in return. If the animals say anything against the will of the pigs or object about any decision that is taken by the pigs, Squealer threatens them with his usual sentence that 'Jones would come back!'

\subsubsection{Pragmatic Analysis}

This textshows the power of language. The animals are always threatened by the speech of Squealer and the other pigs. The pigs use the language and certain words to dominate the animals. This use of language leads to a totalitarian state. This totalitarian language is not used directly, but through implications and hidden meanings. Squealer success in deceiving the animals with vain promises through the use of sentences that have external and internal meanings. The implied meaning of these sentences is made clear through pragmatics and its theories.

\subsubsection{Grice's Maxims}

1. The Quantity Maxim: Squealer violates the quantity maxim. He has been more informative than is required.

2. The Quality Maxim: Squealer violates this maxim because he conveys unjustifiable information.

3. The Relevance Maxim: Squealer's contribution is relevant.

4. The Manner Maxim: Squealer's speech is not clear, he implies the real reason behind the disappearance of the milk and apples.

\subsubsection{Cooperative Principles}

In this extract, the meaning is not stated directly. All the animals understand the surface meaning of Squealer's speech that he wants their benefits, but in fact he deceives them and just want to justify the disappearance of the milk and apples. Squealer has not been cooperative. He tries to hide the real purpose of taking the apples and milk. He gives flimsy excuses and he knows for sure that these idiot animals will believe him. In addition, Squealer and all the pigs whenever they want to shut the mouth of the animals, they threaten them with the coming back of Mr. Jones. The pigs know how to exploit the weak points of the animals. The animals do not want the old totalitarian regime of Mr. Jones to come back, so they keep silent and do not object. Tyranny is spread through words and through a mouthpiece like Squealer. Although Squealer's contribution has been relevant to the context of the exchange, he violates three of the maxims. He gives unneeded untruthful and unclear information to mislead the animals, giving false information and being not orderly.

\subsubsection{Implicature}

Squealer's speech is a clear example of implicature. He implies the aim of the pigs which is to control all the animals by saying that what they do is for the benefit of all the animals. What the speaker says is not exactly what he means. He implies the purpose of his speech by being more informative than is required (giving extra information) and also by giving false information and being not orderly. The type of implicature in this extract is conversational implicature. The implied meaning is uncovered by depending on the context of the conversation. The pigs depend on words to impose their power upon all animals.

\subsection{Analysis of Extract 2}

"My sight is failing, 'she said finally.' Even when I was young I could not have read what was written there. But it appears to me that that wall looks different. Are the Seven Commandments the same as they used to be, Benjamin?' For once Benjamin consented to break his rule, and he read out to her what was written on the wall. There was nothing there now except a single Commandment. It ran: 'ALL ANIMALS ARE EQUAL BUT SOME ANIMALS ARE MORE EQUAL THAN OTHERS'. "

(N 1: P.40) 


\subsubsection{Contextual Analysis}

This extract is said by Clover to Benjamin in the farm. Clover gets older to the extent that she cannot see well around her. She says that she is now illiterate and blind. Benjamin who keeps apart from everything speaks finally and decides to read Clover the seventh commandments. Clover asks a very important question which is whether the seventh commandments are the same as they used to be or have changed? Benjamin answers her saying that there are no seven commandments anymore. There is only one single commandment which is 'All animals are equal, but some Animals are more equal than others.'

\subsubsection{Pragmatic Analysis}

The change of the commandments to a single one which states that not all animals are equal is against the target that the animals fight for. The society of the animals is divided into two classes; the high class 'the pigs' class' and the lower or working class 'the rest of the animals'. The pragmatic function of this extract states that there is no revolution without corruption and corruption comes from the animals themselves.

\subsubsection{Grice's Maxims}

1. The Quantity Maxim: There is no violation to the maxim of quantity.

2. The Quality Maxim: There is a violation to this maxim because the information written in the commandment is not justified.

3. The Relevance Maxim: The contribution is relevant.

4. The Manner Maxim: The contribution is vague and not orderly.

\subsubsection{Cooperative Principles}

The contribution violates two of the maxims. The information in this text is not true, ambiguous and not orderly. The animals do not try to be cooperative. They hide the facts they know and try to be happy in their life while they are not. The animals do not cooperate correctly and clearly. What they say is not the same of what they mean.

\subsubsection{Implicature}

The last line in this extract carries the whole implied meaning. Totalitarianism controls every facet of life. This control reaches till the minds of the animals. They reach the extent to fool themselves and misrepresent the facts. The pigs manipulate everything for their interests. They even manipulate the animals' mind and make them accept the change in everything even in the commandments which are the basic for their rebellion. The violation of the quality and manner maxims make ambiguity be in everything even in the facts that are known to everybody in the farm.

\section{CONCLUSIONS}

On the bases of analysis, it is found that language has a great power in shaping humans' thoughts and convictions. It is used as a tool to control and manipulate people's minds. The pragmatic and contextual analysis show that language is the unique talent of human beings that has a great role in decorating their thoughts and deeds. This great role of language is illustrated by Orwell in his two dystopian novel Animal Farm. Orwell explains how the totalitarian regimes use language to manipulate people's minds and change their thoughts. Since this study deals with showing the power of language, the researcher attempts to focus on the aspects of language which show its power upon humans' thoughts and behaviour. In order to control people's thoughts and expressions, the government gives a threatening image to the language. In Animal Farm, the pigs achieve all their ambitions and desires through exploiting the poor minds of the animals. They are always ready to manipulate their speeches and language to justify their bad deeds whenever they feel that their political status in danger.

Orwell focuses on the role of language in his writings. Language has a great role in affecting 
people's minds, behaviour and even their achievements and decisions. What is found in the pragmatic analysis of the novel is that language does have such influential role in human lives because it is the path to their personality and minds. This research deals with the role of pragmatics in displaying the power that the language has and its implied meanings specifically in the discourse of politicians and how language controls and changes people's mind.

The pragmatic analysis of the first extract shows that language is not used directly, but through implications and hidden meanings. Squealer (the mouthpiece of the pigs) successes in deceiving the animals with vain promises through the use of

\section{REFERENCES}

Abraham, S. (2016). Pragmatics: Historical Development, Scope and Subject Matter or Object of Study. International Journal of Advanced Multidisciplinary Research. 3(12), 37-43. DOI: http://dx.doi.org/10.22192/ijamr.2016.03.12.007

Berkes, J. (2000). Language as the 'Ultimate Weapon' in Nineteen Eighty-Four. Retrievedfrom http://www.berkes.ca/archive/berkes_1984_language.html.

Clark, T. N. (1967). A concept of power: Some overemphasized and underrecognized dimensions. Southwestern Social Science Quarterly, 3, 271.

Crystal, D. (1985). A dictionary of linguistics and phonetics (2nd ed.). Oxford: Blackwell.

Crystal, D. (1987 ). The Cambridge encyclopedia of language. Cambridge: Cambridge University Press.

Denzin, N. \& Lincoln, Y. (2000). Paradigmatic Controversies and Contradictions. Handbook of Qualitative Research. London: Sage Publication Inc.

Elbarbary, S. (1992). Language as Theme in Animal Farm. Kuwait University.

Finsen, S. (2016). The power of language: language policies of international institutions (master thesis). Reykjavík, Ísland.

Goldberg, A. A.; Cavanaugh, M. S. \& Larson, C. E. (1983). The meaning of power. Journal of Applied Communication Research, 11, 89-108.

Grice, H. P. (1989). Studies in the way of words. Cambridge: Harvard University Press.

Grundy, P. (2000). Doing Pragmatics. New York: Oxford University Press. 
Hossain, M. (2017). Language as the Device for Psychological Manipulation in George Orwell's Nineteen EightyFour: A Psychological Linguistic Analysis. European Journal of English Language and Linguistics Research 5(8), 25-31.

Levinson, S. (1983). Pragmatics. Cambridge: Cambridge University Press.

Levinson, S. (1997) Pragmatics. 3rd.ed. Cambridge: Cambridge University Press.

Lupyan, G.; Bergen, B. (2015). How Language Programs the Mind. Topics in CognitiveScience. 1-17. Cognitive Science Society, Inc.

Marin, M. (2014). Language and Mind Control in 1984. Prezi [Web Blog]. Retrieved fromhttps://prezi.com.

Nagel, J .H. (1975). The descriptive analysis of power. New Haven, CT: Yale University Press.

Romaine, S. (1994). Language in society: An introduction to sociolinguistics (2nd ed.). New York, NY: Oxford University Press.

Sari, A. (2014). A Pragmatic Analysis of Speech Acts of the Main Character in State of Play (master's thesis). Yogyakarta: Yogyakarta State University.

Sillince, J. A. A. (2000). Rhetorical power, accountability and conflict in committees: An argumentation approach. Journal of Management Studies, 37, 1125-1156.

Shank, G. (2002). Qualitative Research: A Personal Skills Aproach. New Jersey: Merril Prentice Hall.

Soriano, R. (2010). Manipulation of language as a weapon of mind control and abuse of powerin 1984. Retrieved from www.rurueso.blogs.uv.es.

Spolsky, B. (2004). Language Policy. Cambridge: Cambridge University Press.

Talbot, M., Atkinson, K., \& Atkinson, D. (2003). Language and power in the modern world. Edinburgh: Edinburgh University Press.

Verschueren, J . \& Ostman, J. (2009). Key Notions for Pragmatics. Amsterdam: John Benjamins.

Wright, S. (2000). Communicating across divides: Lingua franca in Europe. In S. Wright, L. Hantrais \& J. Howorth (Eds.), Language, politics and society: the new languages department: Festschrift in honour of Professor D.E. Ager (pp. 119-129). Clevedon: Multilingual Matters ltd.

Yule, G. (1996). The Study of Language (2nd Eds). Cambridge: Cambridge university Press. 